the ions with which they are associated (mainly $\mathrm{Ca}^{2+}, \mathrm{Mg}^{2+}, \mathrm{Mn}^{2+}, \mathrm{K}+$ and $\mathrm{H}^{+}$in natural phytates) and on the level of $\mathrm{Ca}$ in the diet. Thus, native phytates, free phytic acid, sodium and calcium phytates and commercial 'phytin' (a $\mathrm{Ca}-\mathrm{Mg}$ phytate) do not necessarily behave in the same way.

(6) Vitamin $D$ probably enhances the utilization of phytate $P$ in two ways, by increasing the production of intestinal phytase and by stimulating $\mathrm{Ca}$ absorption, thus rendering the phytate more soluble. The requirements of animals for vitamin $\mathrm{D}$ increase as the proportion of the total dietary $\mathrm{P}$ as phytate increases.

\title{
REFERENCES
}

Ashton, W. M. \& Evans, C. (1962). F. Sci. Fd Agric. 13, I68.

Ashton, W. M., Evans, C. \& Williams, P. C. (1960). F. Sci. Fd Agric. 11, 722.

Bruce, H. M. \& Callow, R. K. (1934). Biochem. F. 28, 5 I 7.

Common, R. H. (1940). F. agric. Sci. 30, II 3 .

Gillis, M. B., Norris, L. C. \& Heuser, G. F. (r949). Poult. Sci. 28, 283.

Hill, R. (1962). Wld Rev. Nutr. Diet. 3, I 29.

Hill, R. \& Tyler, C. (1954). F. agric. Sci. 44, 306.

Jenkins, N. K. (1965). Nature, Lond., 205, 89.

Krieger, C. H. \& Steenbock, H. (1940). F. Nutr. 20, 25.

Lowe, J. T. \& Steenbock, H. (1936a). Biochem. F. 30, 199.

Lowe, J. T. \& Steenbock, H. (1936b). Biochem. F. 30, i 126.

McCance, R. A. \& Widdowson, E. M. (1944). Nature, Lond., 153, 650.

Maddaiah, V. 'T., Kurnick, A. A., Hulett, B. J. \& Reid, B. L. (I964). Proc. Soc. exp. Biol., N. Y., I15, I054.

Mellanby, E. (1920). Lancet, i, 856 .

Mellanby, E. (I950). A Story of Nutritional Research. Baltimore: Williams and Wilkins Co.

Moore, J. H. \& Tyler, C. (1955a). Brit, F. Nutr. 9, 63.

Moore, J. H. \& Tyler, C. (1955b). Brit. F. Nutr. 9, 8r.

O'Dell, B. L., Yohe, J. M. \& Savage, J. E. (r964). Poult. Sci. 43, 415.

Oshima, M. \& Taylor, T. G. (1963). Biochem. F. 86, I3P.

Oshima, M., Taylor, T. G. \& Williams, A. (r964). Biochem. F. 92, 42.

Patwardhan, V. N. (1937). Biochem. F. 3r, 560.

Pileggi, V. J., De Luca, H. F. \& Steenbock, H. (1955). Arch. Biochem. Biophys. 58, 194.

Rapoport, S. (1940). F. biol. Chem. r35, 403.

Rapoport, S., Leva, E. \& Guest, G. M. (I94I). f. biol. Chem. 139, 62 r.

Roberts, A. H. \& Yudkin, J. (I96r). Brit. F. Nutr. r5, 457.

Shohl, A. T. (1939). Mineral Metabolism. New York: Reinhold Publishing Corp.

Singsen, E. P. (1948). Bull. Storrs agric. Exp. Sta. no. 260.

Spitzer, R. R. \& Phillips, P. H. (1945). F. Nutr. 30, I83.

Steenbock, H., Krieger, C. H., Wiest, W. G. \& Pileggi, V. J. (1953). F. biol. Chem. 205, 993.

Temperton, H. \& Cassidy, J. (1964). Brit. Poult. Sci. 5, 75.

Tucker, H. F. \& Salmon, W. D. (1955). Proc. Soc. exp. Biol., N.Y., 88, 61 3.

Waldroup, P. W., Ammerman, C. B. \& Harms, R. H. (1964). Poult. Sci. 43, 426.

\section{Bread and other foods of plant origin as a source of iron}

\section{By P. C. Elwood, Medical Research Council Epidemiological Research Unit, Cardiff}

Iron deficiency is probably the commonest dietary deficiency in the world at the present time, and Fe-deficiency anaemia is an important problem in many countries. This is not altogether surprising as the average dietary intake of $\mathrm{Fe}$ in most countries is probably closer to, and more frequently lower than, recommended minimum levels, than is that of any other essential nutrient. Furthermore in times of national or domestic food shortage, some persons are likely to reduce their intake of $\mathrm{Fe}$ to a disproportionate degree, for example the elderly (Hobson \& Pemberton, 1955), and married 
women (Lamott-Barillon, 195I), as these are likely to supplement their diet with carbohydrate foods at the expense of more costly Fe-rich foods of animal origin.

Only a very few isolated groups, such as Eskimos and some pastoral tribes, are predominantly carnivorous. In all other communities foods of plant origin form a large part of the diet, and contribute a large proportion of the total $\mathrm{Fe}$ intake. In this country almost half the total calories and over half the total dietary Fe come from plant sources, and in the larger households these proportions are even higher (Table I).

Table I. Intake of iron per person per day from various foods consumed in 1961 by persons in all households, and persons in households with two adults and four or more children (from Ministry of Agriculture, Fisheries and Food: National Food Survey Committee, 1963)

\begin{tabular}{|c|c|c|c|c|}
\hline \multirow[b]{2}{*}{ Food } & All ho & seholds & $\begin{array}{r}\text { per persons } \\
\text { House } \\
\text { two } \\
\text { and four o. }\end{array}$ & $\begin{array}{l}\text { eer day } \\
\text { olds with } \\
\text { tdults, } \\
\text { more children }\end{array}$ \\
\hline & $\mathrm{mg}$ & $\%$ & $\mathrm{mg}$ & $\%$ \\
\hline All meats & 3.8 & $27 \cdot 1$ & $2 \cdot 5$ & $22 \cdot 0$ \\
\hline All fish & 0.3 & $2 \cdot 1$ & 0.2 & I.5 \\
\hline Dairy produce & 0.5 & $3 \cdot 7$ & 0.5 & $4 \cdot 2$ \\
\hline All foods of animal origin & $5 \cdot 9$ & $4 I \cdot 9$ & $4 \cdot I$ & $36 \cdot 3$ \\
\hline $\begin{array}{l}\text { All cereals } \\
\text { (White bread) }\end{array}$ & $\begin{array}{l}4 \cdot 8 \\
(2 \cdot 2)\end{array}$ & $\begin{array}{l}34 \cdot 2 \\
(15 \cdot 7)\end{array}$ & $\begin{array}{l}4 \cdot 3 \\
2 \cdot 3\end{array}$ & $\begin{array}{c}38 \cdot 1 \\
(20 \cdot 9)\end{array}$ \\
\hline All vegetables & $2 \cdot 6$ & 18.0 & $2 \cdot 3$ & $20 \cdot 3$ \\
\hline All fruit & 0.5 & $3 \cdot 8$ & 0.3 & $2 \cdot 7$ \\
\hline All foods of plant origin & $8 \cdot 3$ & $5^{8 \cdot 1}$ & $7 \cdot 1$ & $63 \cdot 7$ \\
\hline All foods & $14 \cdot 2$ & $100 \cdot 0$ & I $1 \cdot 2$ & $100 \cdot 2$ \\
\hline
\end{tabular}

The Fe content of various foodstuffs has been determined by many workers, and extremely comprehensive tables of the Fe content in individual items of food have been published by McCance \& Widdowson ( 1960 ), and others. However, the total Fe content of plants can vary considerably even if grown under normal conditions, and these variations are considerably greater for $\mathrm{Fe}$ than for other minerals (Ranganathan, 1938). For example, turnips are said to vary by up to $400 \%$ in their Fe content (Asenjo, 1962), wheat by almost as much (Free \& Bing, 1940), and cabbages by about $300 \%$ (Ranganathan, 1938). In general, the important factors that lead to an increase in $\mathrm{Fe}$ content appear to be a high soil temperature, a high humidity and a high content of organic matter in the soil. Important factors that may lead to a decrease in $\mathrm{Fe}$ content are a high rainfall and increasing age of the plants (Asenjo, 1962). It is surprising that the Fe content of the soil does not appear to be an important source of variation in the Fe content of plants grown in it. Most soils contain an excess of $\mathrm{Fe}$ and the top $6 \mathrm{in}$. is said to contain often 20 tons or more of Fe per acre. Most is present as ferric oxide and is not available to plants, but much is in other forms, particularly if the soil is acid, and about $2 \mathrm{lb}$ of available Fe per acre is sufficient for the requirements of most plants. A deficiency can usually be easily 24 (I) 8 
remedied by the addition of $\mathrm{Fe}$ to the soil, though its availability to plants depends to a considerable degree on a balance with other minerals. Chlorosis of plants, a condition which includes leaf yellowing and stunted growth due to a lack of chlorophyll, can result from primary Fe deficiency, but it can also be caused by manganese deficiency, or an excess of calcium. This so-called 'lime induced chlorosis' is actually caused by a precipitation of Fe within the plant so that, although rich in Fe, it is deficient in physiologically active $\mathrm{Fe}$, and it is doubtful if this precipitated Fe is available to man if the plant is consumed. Unfortunately, it seems unlikely therefore that the useful Fe content of plants can be augmented simply by the addition of $\mathrm{Fe}$ or by a change in the ratio of $\mathrm{Fe}$ to other minerals in the soil (G. F. Asprey and D. J. Carr, personal communications).

The importance of the variations in the total Fe content of plants has been stressed by Ranganathan (1938). Furthermore, Bransby, Daubney \& King ( $194^{8-9}$ ) found that the Fe content of the diet of a group of adults was considerably higher when determined by analysis ( $19 \mathrm{mg}$ per person per day on average) than when estimated from food tables (I I mg per person per day), and they believe therefore that for individual purposes calculations of nutritive indices have little value. However, even apart from these errors in estimation, measurement of the total Fe content of a foodstuff is of limited value, as it ignores the relative availability of the Fe.

The rat has been the experimental animal most frequently used to examine the availability of $\mathrm{Fe}$ in different foods (Smith \& Otis, 1937; Free \& Bing, r940; Pye \& McLeod, 1946), and studies on dogs seem to have given roughly similar results (Ruegamer, Michaud, Hart \& Elvehjem, I946).

However, man is no rat, and it is unlikely that conclusions based on animal experiments are always of direct relevance to man. Indeed certain findings seem to indicate that animals do not handle $\mathrm{Fe}$ in a manner similar to man. These include the fact that ferrous and ferric salts are equally available to the rat (Austoni \& Greenberg, I940; Venkatachalam, Brading, George \& Walsh, 1956) and to the dog (Moore, Dubach, Minnich \& Roberts, 1944) but not to man (Brise \& Hallberg, 1962). Of particular relevance to possible differences in the absorption of food Fe by animals and by man is the finding that rats secrete a phytase (Patwardhan, I937) and the fact that the protein-bound $\mathrm{Fe}$ in haemoglobin is about five times less well absorbed by the rat than by man (Bothwell \& Finch, 1962).

Unfortunately, investigation of $\mathrm{Fe}$ absorption from individual foodstuffs by human subjects is extremely difficult, so it is not surprising that there have been relatively few studies in man and that the results of reported studies have shown considerable differences. Dietary balance studies of the uptake of Fe from individual foods have been presented by Widdowson \& McCance (I942), McMillan \& Johnston (195I) and others, and these have been critically reviewed by Josephs (I958), who stressed their value and accuracy. The absorption of $\mathrm{Fe}$ from individual foods labelled with radioactive $F e$ has been studied by Moore \& Dubach (1955), Steinkamp, Dubach \& Moore (1955), Chodos, Ross, Apt, Pollycove \& Halkett (I957) and others.

However, Pirzio-Biroli, Bothwell \& Finch (1958) have pointed out that a measure of the absorption of Fe from a complete meal is more realistic than measures of 
absorption from individual foodstuffs. This can be estimated by diet balance studies, but unfortunately a complete meal cannot be tagged with radioactive iron. PirzioBiroli et al. (1958) overcame this difficulty by measuring the uptake of a small dose of radioactive $\mathrm{Fe}$ as ferrous chloride given during a 'standard' meal. They assumed, as did Sharpe, Peacock, Cooke \& Harris (1950), that the relative absorption of the added inorganic $\mathrm{Fe}$ is similar to that of the naturally occurring $\mathrm{Fe}$ in the food, and they pointed out that much of the food $\mathrm{Fe}$ is probably converted in the stomach into chloride, but it is doubtful if these assumptions are valid. Nevertheless, it is of interest that, as pointed out by Moore (196r), the mean absorptions of the inorganic iron given together with a complete meal by Pirzio-Biroli et al. (1958) and by Sharpe et al. (1950) $(5.3$ and $4.4 \%$ respectively) are in remarkably close agreement with the overall average absorption of food $\mathrm{Fe}(6.5 \%)$ in 133 experiments reported by various workers who estimated the absorption in individual human subjects from a wide range of single foodstuffs.

Factors other than the initial le content of a foodstuff, or meal, have been shown to be of relevance in this context. These include whether or not juices and cooking fluids are consumed (Davidson, Meiklejohn \& Passmore, 1959), the presence of reducing substances such as ascorbic acid in the meal (Moore, 1955), the bulk of the meal (Sharpe et al. 1950; Brise, 1962), and whether or not Fe cooking vessels are used (Walker \& Arvidsson, 1953), though it is doubtful if this last factor is of importance in Great Britain (Mackay, Dobbs, Bingham \& Martin, 1946). Factors within the individual have also been shown to be of importance; thus in addition to differences between subjects, absorption by a single subject varies considerably from day to day (Brise \& Hallberg, 1962), absorption by Fe-deficient subjects is probably about three times as efficient as that in normal subjects (Moore, 1959), and absorption is better, and more consistent, in children than in adults (Josephs, 1958). Indeed it is likely that, with regard to the absorption of food Fe, factors such as these are together of relatively greater importance than the initial Fe content of the individual foodstuffs or a diet.

It is probable that, of all individual foodstuffs, cereals are the most important in almost every country, both as a source of calories and of Fe. In most agricultural communities, and in particular in Africa and Asia, cereals alone form the major part of the diet, whereas in this country cereals contribute almost one-third of the total calories, and about the same proportion of the total $\mathrm{Fe}$ in the diet (Ministry of Agriculture, Fisheries and Food: National Food Survey Committee, 1963). Certainly cereals are of major importance to man. Davidson et al. (1959) have pointed out that stable civilizations have only arisen when primitive hunting communities learned to raise successive cereal crops, and without these crops man is reduced to an uncertain and nomadic life. Cereals have a relatively high $\mathrm{Fe}$ content; most wheats are particularly rich and have about $4 \mathrm{mg} / \mathrm{roO} \mathrm{g}$ whole grain, and wheat flours of high extraction (over $85 \%$ ) have usually between 2 and $3 \mathrm{mg} \mathrm{Fe} / \mathrm{loo} \mathrm{g}$ flour. This is well utilized by anaemic rats (Rose, Vahlteich \& McLeod, 1934; Smith \& Otis, 1937; Free \& Bing, 1940; Pye \& McLeod, 1946), but its availability to man is almost certainly low, probably owing to the presence of phytates (Widdowson \& McCance, 
I942; Hussain \& Patwardhan, 1959). However, since 1957, after the report of the Panel on the Composition and Nutritive Value of Flour (Great Britain: Parliament, $195^{6 c}$ ) all white bread in this country made from low extraction flours has had up to $\mathrm{I} \cdot 65 \mathrm{mg}$ Fe added per $100 \mathrm{~g}$ flour to restore the naturally occurring $\mathrm{Fe}$ which is removed by milling. This $\mathrm{Fe}$ is in the form of reduced iron and, though the Bread and Flour Regulations (Great Britain: Parliament, 1963) which have re-enacted the Flour (Composition) Regulations (Great Britain: Parliament, $1956 a, b$ ) also permit the use of ferric and ammonium citrate, only reduced $\mathrm{Fe}$ appears to be used in this country.

Unfortunately, there have been very few studies of the value to man of the fortification of flour with Fe. Mackay, Dobbs \& Bingham (r945) found that the addition of $\mathrm{Fe}$ as ferrous carbonate to flour at a level sufficient to give $14^{-20} \mathrm{mg} \mathrm{Fe}$ daily to nursery schoolchildren had no appreciable effect on their haemoglobin levels. Widdowson \& McCance (I954) studied undernourished children in Germany, and found that they grew equally well whether given bread made from wholemeal flour or unenriched $70 \%$ extraction flour or $70 \%$ extraction flour enriched to wholemeal levels with $\mathrm{Fe}$ (presumably reduced), and after I year the haemoglobin and haematocrit levels of the groups given these diets showed no significant differences (at $P<0.05$ ). Steinkamp et al. (1955), using radioactive Fe incorporated into the four compounds most commonly used in the USA for enrichment of flour, concluded that the salts tested, which included reduced $\mathrm{Fe}$ and ferrous sulphate, are more or less equally well absorbed from bread by human subjects, though their availability, both when given baked into bread and when given together with a meal of bread, was low but similar. The five 'normal' subjects to whom Steinkamp et al. gave bread enriched with reduced $\mathrm{Fe}$ absorbed only $10 \%$ or less of the added $\mathrm{Fe}$, but two subjects, both of whom were thought to be Fe-deficient, absorbed considerably more. Harrill, Hoene \& Johnston ( 1957) also concluded, from Fe balance studies in young women, that differences in the availability from bread of the three inorganic Fe preparations they tested (ferrous sulphate, ferric phosphate and reduced $\mathrm{Fe}$ ) were unimportant, but the mean absorption in their nine 'normal subjects' was only $3 \%$ and this figure was largely due to two subjects who 'absorbed well'.

These studies are of considerable interest, but they do suffer from the limitation that all the subjects involved were healthy and, other than two of the subjects studied by Steinkamp et al. (1955) who may have been Fe-deficient, and possibly the subjects of Widdowson \& McCance (I954), they were in no need of Fe beyond that required to make good their normal daily losses, which were probably very small indeed. Thus a low absorption in studies such as these may simply indicate a rejection of $\mathrm{Fe}$ which the subjects did not require, rather than an inability to absorb more than a fraction of the added Fe.

A more simple approach is to study the effect on haemoglobin level of the $\mathrm{Fe}$ preparations of interest in this context, when given in therapeutic amounts to groups of subjects, although it is by no means certain that the efficiency of absorption of large amounts of $\mathrm{Fe}$ is a true index of the availability of much smaller amounts such as those that are added to flour. 
However, there does seem to be some doubt as to the therapeutic value of reduced Fe. It is well utilized by anaemic rats for haemoglobin regeneration (Nakamura \& Mitchell, 1943; Freeman \& Burrill, 1945), but its availability to man is less clearly established. Hemmeler ( $195 \mathrm{I})$ stated that posthaemorrhagic and nutritional anaemias respond well to reduced Fe, and Bethell, Goldhamer, Isaacs \& Sturgis (1934) reported a satisfactory response of anaemia to it in large doses, but noted that ferric ammonium citrate was equally effective in doses which contained approximately half the amount of elemental Fe. Fowler \& Barer (1937) noted a rise in the haemoglobin level of thirteen subjects who had 'mild anaemia' (mean haemoglobin level $10.17 \mathrm{~g}$ ) and who were given I $g$ reduced $\mathrm{Fe}$ per day, but it is of interest to note that the mean rise shown by this group $(\mathrm{r} \cdot 7 \mathrm{~g} \mathrm{Hb})$ was less than that shown by a similar group of subjects $(2 \cdot \mathrm{Ig} \mathrm{Hb})$ each of whom was given about one-sixth the amount of elemental $\mathrm{Fe}$ as ferric ammonium citrate daily. However, Witts (1936) estimated the absorption of ferrum redactum to be only $0.5-2 \cdot 0 \%$, whereas that of ferrous sulphate he estimated to be $14 \%$, though he based these estimates on very different doses of the two preparations. In an attempt to treat Fe deficiency Elwood ( 1963 ) gave groups of hospital patients about $80 \mathrm{mg} \mathrm{Fe} /$ day for 6 months as reduced $\mathrm{Fe}$ baked into bread, but failed to demonstrate any therapeutic effect. A similar amount of $\mathrm{Fe}$ as ferrous gluconate given in tablets to a similar group of patients caused a reasonable rise in their mean haemoglobin level, and the differences between the groups were considerably greater in patients with low initial haemoglobin levels.

Unfortunately it was not possible in the experiment of Elwood (1963) to incorporate the ferrous gluconate in the bread as such large amounts cause the bread to be unpalatable. Therefore the difference in response could have been a consequence of the incorporation of reduced $\mathrm{Fe}$ in bread rather than of its being a less therapeutic agent than ferrous gluconate. It does seem unlikely that this is the whole explanation, however, as Stott (1960), who incorporated sufficient ferrous sulphate in bread to give an extra $50 \mathrm{mg}$ elemental $\mathrm{Fe}$ per day to $\mathrm{I} 24$ prisoners in Mauritius, noted a significant and sustained rise in their mean haemoglobin level after a few months. However, to examine this point further, the therapeutic effects of ferrous gluconate and reduced $\mathrm{Fe}$, both in tablet form, were compared in mental hospital patients all of whom had presumptive evidence of $\mathrm{Fe}$ deficiency (P. C. Elwood, unpublished results). As the Bread and Flour Regulations (Great Britain: Parliament, 1963) list ferric and ammonium citrate as an alternative to reduced $F e$ for the fortification of flour, this preparation was also included in the trial. After 12 weeks' therapy, during which all the patients received I ro mg elemental Fe per day, except a control group which received no additional $\mathrm{Fe}$, sixteen patients who had received reduced $\mathrm{Fe}$ and twenty who had received ferric and ammonium citrate showed mean rises in both haemoglobin level and mean corpuscular haemoglobin concentration which were small, but were similar in size and differed significantly (at $P<0.05$ ) from that of a control group of twenty-three patients who received no Fe therapy, while sixteen patients who had received ferrous gluconate showed no change that differed significantly from those of the control group (Table 2). The absence of a significant response to ferrous gluconate is surprising and, though no explanation could be 
found, it could suggest that mental hospital patients are not entirely satisfactory subjects for such studies. However, these findings taken in conjunction with those of the other authors quoted seem to indicate that reduced $\mathrm{Fe}$ is of some, though perhaps limited, therapeutic value.

Table 2. Changes in the mean haemoglobin levels, etc. of three groups of patients given iron therapy for 12 weeks. The figures shown are the differences between the change within each group, and the change shown by a control group given no additional Fe

$\begin{array}{llcc}\text { Variable } & \overbrace{}^{\text {Reduced Fe }} & \begin{array}{c}\text { Ferric ammonium } \\ \text { citrate }\end{array} & \begin{array}{c}\text { Fertous } \\ \text { gluconate }\end{array} \\ \begin{array}{l}\text { Haemoglobin level } \\ (\mathrm{g} \mathrm{Hb} / 100 \mathrm{ml})\end{array} & 0.50 \pm 0.17^{*} & 0.60 \pm 0.23^{*} & 0.18 \pm 0.30 \\ \begin{array}{l}\mathrm{MCHC} \\ (\%)\end{array} & 1.74 \pm 0.79^{*} & 1.78 \pm 0.68^{*} & 0.37 \pm 0.77 \\ \begin{array}{l}\text { Serum Fe } \\ (\mu \mathrm{g} / 100 \mathrm{ml})\end{array} & { }_{1.87 \pm 11.43} & 20.01 \pm 13.17 & 6.00 \pm 12.97 \\ & * \text { Significant at } P<0.05 . & \end{array}$

Nevertheless, these studies have led to the initiation of further work in conjunction with the Cereal Research Station at St Albans, which is still in progress. Certainly the more closely the problems relating to the addition of reduced Fe to flour are examined the more complex they seem to be. For example, freshly prepared reduced $\mathrm{Fe}$ is highly reactive and on exposure to the atmosphere the particles rapidly become coated with firmly adherent oxides, most of which are probably ferric oxide. This film of oxide appears to impair the solubility in dilute acid of reduced $\mathrm{Fe}$ considerably. Of a $50 \mathrm{mg}$ sample of reduced $\mathrm{Fe}$ prepared a considerable time before testing, solution in $100 \mathrm{ml}$ of $0.1 \mathrm{~N}$-hydrochloric acid at $40^{\circ}$ progressed at an almost imperceptible rate, and even after it h nearly $20 \%$ remained undissolved, whereas a freshly reduced sample tested under identical conditions had completely dissolved in under $7 \mathrm{~h}$ (C. Graham \& P. C. Elwood, unpublished results). Though the environment within a loaf during the baking process is probably one of reduction, it may well be that before, and possibly after, baking the environment is one of oxidation. In any event, the particles of ferrum redactum, being highly reactive, are likely to be coated with oxide even before the baking process commences, and as ferric oxide is very stable it is unlikely to be reduced to any extent during the baking process.

In rats a coating of ferric oxide may well have little effect on the absorption of reduced $\mathrm{Fe}$, as ferric salts have been noted to be readily available to the rat and therefore one is not surprised by the favourable results of Freeman \& Burrill (1945), Blumberg \& Arnold (I947) and others, all of whom based their studies of the availability of reduced $\mathrm{Fe}$ from bread on severely anaemic rats. However, in man a surface film of ferric oxide is likely to impair the absorption of reduced $\mathrm{Fe}$ as the availability of ferric oxide to man is probably very low, and if the coat of oxide on the particles is complete it is likely to confer a considerable degree of insolubility to the encapsulated Fe. 
The desirability of ensuring that the Fe added to flour is readily available to man is apparent from Table I. A considerable proportion of our Fe intake in this country comes from cereals, and of the Fe in bread, and much of the other cereal foods, about half is present in its natural form, and the remainder is reduced Fe. The naturally present $\mathrm{Fe}$ is believed to be in the form of a phytate, and though its availability to man is not known with certainty, it may well be that reduced Fe, whatever its drawbacks, is at least as readily available. However, in collaboration with the Cereal Research Station work is still in progress and one further promising line of investigation appears to be the relation to availability of the particle size of reduced Fe currently added to flour.

I am indebted to Professor J. Pemberton of the Department of Social and Preventive Medicine, The Queen's University of Belfast, Dr T. Moran of the Cereals Research Station, St Albans, and Dr W. T. C. Berry of the Ministry of Health, for advice and encouragement, and for having initiated much of the original work presented here.

\section{REFERENCES}

Asenjo, C. F. (1962). Amer. F. clin. Nutr. r1, 368.

Austoni, M. E. \& Greenberg, D. M. (1940). F. biol. Chem. 134, 27.

Bethell, F. H., Goldhamer, S. M., Isaacs, R. \& Sturgis, C. C. (1934). F, Amer. med. Ass. 103, 797.

Blumberg, H. \& Arnold, A. (1947). Cereal Chem. 24, 303.

Bothwell, 'T. H. \& Finch, C. A. (1962). Iron Metabolism. London: Churchill.

Bransby, E. R., Daubney, C. G. \& King, J. (1948-9). Brit. F. Nutr. 2, 232.

Brise, H. (1962). Acta med. scand. I71, suppl. 376, p. 39.

Brise, H. \& Hallberg, L. (1962). Acta med. scand. 171, suppl. 376, p. 7.

Chodos, R. B., Ross, J. F., Apt, L., Pollycove, M. \& Halkett, J. D. E. (1957). F. clin. Invest. 36, 314.

Davidson, S., Meiklejohn, A. P. \& Passmore, R. (1959). Human Nutrition and Dietetics. Edinburgh and London: Livingstone.

Elwood, P. C. (1963). Brit. med. F. i, 224.

Fowler, W. M. \& Barer, A. P. (1937). Arch. intern. Med. 59, 56r.

Free, A. H. \& Bing, F. C. (1940). F. Nutr. x9, 449.

Freeman, S. \& Burrill, M. W. (1945). \%. Nutr. 30, 293.

Great Britain: Parliament (1956a). The Flour (Composition) Regulations, 1956. Stat. Instrum. no. I I 83.

Great Britain: Parliament (1956b). The Flour (Composition) Regulations, 1956. Stat. Instrum. no. 1354.

Great Britain: Parliament (1956c). Report of the Panel on Composition and Nutritive Value of Flour. [Cmd. 9757]. London: H.M. Stationery Office.

Great Britain: Parliament (1963). The Bread and Flour Regulations, 1963. Stat. Instrum. no. 1435.

Harrill, I. K., Hoene, A. E. \& Johnston, F. A. (1957). F. Amer. diet. Ass. 33, 1010.

Hemmeler, G. (1951). Metabolisme du Fer. Paris: Masson \& Cie.

Hobson, W. \& Pemberton, J. (1955). Health of the Elderly at Home. London: Butterworths.

Hussain, R. \& Patwardhan, V. N. (1959). Indian F. med. Res. 47, 676.

Josephs, H. W. (1958). Blood, r3, r.

Lamotte-Barillon, S. (1951). Y. Amer. med. Wom. Ass. 6, г.

McCance, R. A. \& Widdowson, E. M. (1960). Spec. Rep. Ser. med. Res. Coun., Lond., no. 297.

Mackay, H. M. M., Dobbs, R. H. \& Bingham, K. (1945). Arch. Dis. Childk. 20, 56.

Mackay, H. M. M., Dobbs, R. H., Bingham, K. \& Martin, W. J. (1946). Arch. Dis. Childh. 21, 145

McMillan, T. J. \& Johnston, F. A. (1951). F. Nutr. 44, 383.

Ministry of Agriculture, Fisheries and Food: National Food Survey Committee. (1963). Domestic Food Consumption and Expenditure: 1961. London: H.M. Stationery Office.

Moore, C. V. (1955). Amer. F. clin. Nutr. 3, 3.

Moore, C. V. (196r). Harvey Lect. 55, 67.

Moore, C. V. \& Dubach, R. (1955). In Modern Trends in Blood Diseases. [J. F. Wilkinson, editor.] London: Butterworths.

Moore, C. V., Dubach, R., Minnich, V. \& Roberts, H. K. (1944). Y. clin. Invest. 23, 755.

Nakamura, F. I. \& Mitchell, H. H. (1943). F. Nutr, 25, 39. 
Patwardhan, V. N. (1937). Biochem. F. 3r, 560.

Pirzio-Biroli, G., Bothwell, T. H. \& Finch, C. A. (1958). F. Lab. clin. Med. 51, 37.

Pye, O. F. \& MacLeod, G. (1946). F. Nutr. 32, 677.

Ranganathan, S. (1938). Indian $\mathcal{F}$. med. Res. 26, I 19.

Rose, M. S., Vahlteich, E. M. \& MacLeod, G. (1934). F. biol. Chem. 104, 217.

Ruegamer, W. R., Michaud, L., Hart, E. B. \& Elvehjem, C. A. (1946). F. Nutr. 32, Ior.

Sharpe, L. M., Peacock, W. C., Cooke, R. \& Harris, R. S. (1950). F. Nutr. 4x, 433.

Smith, M. C. \& Otis, L. (1937). F. Nutr. 13, 573.

Steinkamp, R., Dubach, R. \& Moore, C. V. (1955). Arch. intern. Med. 95, I81.

Stott, G. (1 960). Bull. Wld Hlth Org. 23, 781 .

Venkatachalam, P. S., Brading, I., George, E. P. \& Walsh, R. J. (1956). Aust. F. exp. Biol. 34, 389.

Walker, A. R. P. \& Arvidsson, U. B. (1953). Trans. R. Soc. trop. Med. Hyg. 47, 536.

Widdowson, E. M. \& McCance, R. A. (1942). Lancet, i, 588.

Widdowson, E. M. \& McCance, R. A. (1954). Spec. Rep. Ser. med. Res. Coun., Lond., no. 287.

Witts, L. J. (1936). Lancet, $i$, 1.

\section{Relative availability of strontium in flour and milk}

\section{By T. E. F. Carr, G. E. Harrison, J. F. Loutit and Alice Sutton, Medical Research Council, Radiobiological Research Unit, Harwell, Berks.}

Interest in the turnover of strontium in living material stems from the fact that certain radioactive forms of this element are products of nuclear fission. The longest lived radioactive isotope of $\mathrm{Sr}$ is ${ }^{90} \mathrm{Sr}$ which is potentially one of the most dangerous of the fission products not only because of its long physical half-life ( 28 years) but because like calcium, to which $\mathrm{Sr}$ is chemically related, it is transported along the food chain to man (Comar, Russell \& Wasserman, 1957) and ultimately deposited in bone in close proximity to the radio-sensitive haematopoietic tissue of bone marrow.

The assays of dietary constituents for stable Sr (Bryant, Chamberlain, Spicer \& Webb, I956; Agricultural Research Council Radiobiological Laboratory, I959) have shown that it is widely distributed in human diet. Drinking water also contains $\mathrm{Sr}$, the concentration varying in different parts of the country. For an average diet in the United Kingdom, dairy products and water each account for about $13 \%$ of the total intake of $\mathrm{Sr}$, plants and root vegetables for about $28 \%$ and the fortification of national flour by the addition of creta praeparata (calcium carbonate) for about $40 \%$. The normal dietary intake of $\mathrm{Sr}$ by adults is about $2 \mathrm{mg} /$ day, of which some $90 \%$ is found in the stools and some $10 \%$ in the urine (Harrison, Raymond \& Tretheway, I955; Spencer, Laszlo \& Brothers, 1957).

Although certain claims have been made that $\mathrm{Sr}$ is an essential trace element for plant and animal growth, further evidence is required before an unequivocal conclusion can be made. However, no deleterious effects on growth attributable to the normal abundance of $\mathrm{Sr}$ in the food chain have been reported. The numerous experiments on animals and man designed to limit the gastro-intestinal absorption of $\mathrm{Sr}$ have had as their common object, therefore, a decrease in the uptake of ${ }^{0} \mathrm{Sr}$ which is also a component of contemporary diet.

The advent of nuclear fission has given considerable stimulation to the study of many aspects of gastro-intestinal absorption, mechanisms of kidney filtration, not to mention rates of bone turnover and changes in this turnover with age. Thus, some 